TURIZAM

Volume 21, Issue 3

132-138 (2017)

ORIGINAL

SCIENTIFIC PAPER

\section{Canine Events As A Segment Of Tourism Offer}

\author{
Milosava Matejević ${ }^{A}$ \\ Received: August 2017 | Accepted: September 2017 \\ DOI: 10.5937/turizam21-16112
}

A well-planned and organized dog competition is a serious event with a large number of visitors. It has great cynologic, but also economic and tourist importance for the city and the country in which it is organized. Seriously organized dog competitions with a large number of registered dogs and competitors, regardless of whether they are of national or international significance, bring together a large number of people, among them not only competitors, but also members of the organizing team, judges, trainees, volunteers, exhibitors, veterinarians, observers and others. Among the visitors, there are a large number of people traveling far from the place of residence to participate in these competitions. Canine events (competitions in the work and beauty of dogs) are characterized as specific, thematic, interactive and public events with sports-recreational, business and entertainment character. During these events dogs are classified in beauty or a certain type of work. As such, dog events can significantly contribute to the improvement of the tourism product of a certain area, as well as the entire touristic product of Serbia.

Keywords: canine events, event tourism, hunting tourism

\title{
Introduction
}

Events are an important motive for tourist movements and planned events can have great significance in increasing competitive advantage of tourist destinations (Getz, 2008). Event tourism, as a market segment, consists of those people who travel to attend certain events or who can be motivated to attend events while traveling (Mehndiratta, 2008). Bjeljac (2006, 8) points out that "events of a tourist character signify public performance or presentation in the form of an exhibition, an event, or several events of various categories of human achievement, which are distinguished by their specificity, realizing the tourist effects". According to Bowdin et al. $(2011,17)$ "events are special rituals, presentations, performances or celebrations that are continuously designed and created to mark special occasions and/or achieve specific social, cultural or business goals". Getz (2008) describes the event as a unique spatial-temporal phenomenon, because it represents interaction, the interaction of the environment and people. Getz

A Department of geography, tourism and hotel management, Faculty of Sciences, University of Novi Sad, Trg Dositeja Obradovića 3, 21000 Novi Sad, Serbia; milosava_devic@yahoo.com 
(2008) pointed out that the greatest charm of every event is that it's never the same, but you have to be there to experience it fully.

A large number of authors agree that to the offer of a certain tourist destination events play a significant travel, cultural, and social role as well as to contribute to local and the entire regional development (Getz, 1993, 2008; Light, 1996; Formica, Uysal, 1998; Higham, Hinch, 2002; Felsenstein, Fleischer, 2003; Gursoy et al., 2004; Hadžić, 2006; Štetić, 2006; Jackson, 2008; O'Sullivan et al., 2009; O'Sullivan et al., 2009; Dragićević, 2012; Avgousti, 2012) as such may affect the growth of the local tourism demand, creating a better image of the community, increasing the level of attractiveness of the tourist destination, the extension of the tourist season.

Especially because of the positive economic effects left by tourism events, destinations around the world tend to improve organization of special events. Mossberg (200o) points out that a particular event can be viewed as a tourist attraction by itself, but that, unlike specific tourist attractions, its attractiveness changes over time.

Canine events can contribute to the development of event tourism in certain destinations. A well-planned and organized dog competition represents a serious event with a large number of visitors (Matejevic et al., 2014; 2015). It could be of great cynologic, but also economic and tourist significance for the city and the country in which event is maintained. These are specific events that can be observed in several ways, bearing in mind that they have characteristics of different types of events.

\section{Defining canine competitions in the context of event tourism}

Canine events, or dog competitions, especially large international competitions are today events that attract a large number of visitors, and can be observed and characterized in many ways. Dog competitions, as events, are difficult to classify in a particular group, as they have features of different types of events. Bearing in mind that a canine event can have economic, festival, sports and recreational, fair, business and tourist character, it can meet the different needs and wishes of the visitor. Seriously planned and organized national or international dog competitions with a large number of registered dogs and competitors, bring together a large number of people. Among them are not only competitors, but also members of the organizing team, judges, scribes, trainees, volunteers, exhibitors, veterinarians, observers and others. Among the visitors there are a large number of people traveling from the place of residence to participate in these competitions. Since they most often spend at least one night outside the place of permanent residence, they can be considered as tourists.

Canine events are very specific events, which could last one to four days, depending on their character, and within which dogs are evaluated and classified in beauty or in a certain type of work. These competitions are often accompanied by a number of other non-competitive activities such as demonstration of various types of dog sports ("agility", "mondioring", "dog dancing") or even presentation and sale of various dog products within consumer exhibitions. Canine events may have local, regional, national or international character. Bjeljac (2006) points out that the rank of the manifestation is determined by the origin of the participants and visitors. He states that if the visitors and participants are predominantly of domicile origin, the event has a local ranking; if participants and visitors are from the region where the event is held, the event has regional rank. Participants and visitors from the whole country give the event national significance, while events involving foreign participants and visited by 
foreign visitors have international significance. National and international dog events are the most interesting in the context of tourism activities (Matejevic et al., 2013). However, it should be borne in mind that the rank of canine events is determined, above all, by the significance of the candidatures awarded at the competition. The awarding of the candidature for the international champion gives the event an international significance, and the nomination for the national champion gives a manifestation national importance. Well organized and attractive national dog competitions could be events of national importance with international participation, while some international canine events do not include the participation of foreign competitors, especially if they carry the reputation of badly organized ones.

\section{Characteristics of canine events}

Canine events are most often observed in the context of events with competitive character. Bjeljac (2006) places the dog shows in sports-recreational manifestations and a special kind of manifestations of sport character in which the main actors are animals. He emphasizes that "the quality of such events is not primarily contributed by the renown of the participants, but also the quality of the content of the event." However, a large number of dogs in a particular competition, which implies strong competition and high quality dogs, is a factor that significantly, if not the most significant, affects the attendance of the event.

Certainly the most significant element of the cynology event are the participants and competitors. These are the owners and exhibitors of the registered dogs. This group of visitors is, of course, the most interesting from the aspect of tourism, as competitors are ready to cross a certain distance in order to participate in a certain dog competition. However, among competitors there are two groups who are not equally motivated in the competition. The first group is made up of the owners of the dogs registered at the competition. They come to a dog event in order to exhibit their dogs and compete with other dogs. Second group is made up of the professional dog guides so-called "handlers". This group represents people who may not have their own dogs registered at competition, but they expose a dog(s) of one or more owners. Therefore, it is a group of visitors who is primarily motivated by business reasons. Professional dog guides in hunting dogs competitions are often, also, the professional dog trainer.

However, there are still a significant number of dog owners who expose their dogs by themselves. They are motivated to travel by winning at important dog competition. Every victory increases the value of their dogs, both breeding dogs and puppies. Unlike business tourists whose travel and accommodation costs are paid, these owners and breeders pay all expanses by themselves. According to World Tourism Organization, tourist is a traveler who spent at least one night out of the place of permanent residence, and business tourists include also self-employed (who finance their business trips themselves). So, this group of competitors can also be considered as tourists. They can be classified as a group of business tourists, since the main motive for their journey is not purely touristic, but it is inspired by competitive and business ambitions.

Canine events are, also, visited by visitors who do not compete in the event and among them are also two groups of visitors. First group consists of dog breeders, more precisely visitors who are usually engaged in cynology, but do not compete in the specific competition they visited. They did not come to the event to compete with their dogs, but only to observe the course of the competition and the results that other dogs achieved that day. The second group consists of dog lovers who do not have cynology as professional or hobby activity, but simply 
enjoy dogs in their free time. This group of visitors rarely visits hunting dog events, but more often dog exhibitions organized in their city or very close surroundings. They most often come with friends or family, since these events are very interesting for children. It is questionable how many ordinary dog lovers are willing to travel in order to visit a particular dog show and how much this group of visitors is interesting as tourists. All dog owners and exhibitors strive to display their dogs in the best light at these manifestations, which is especially appealing to ordinary visitors of exhibitions, who often do not have the opportunity to see rare dog breeds or dogs specially prepared for such competitions. For dog lovers, visiting these kind of manifestation, it is a form of leisure and leisure activities. If not as tourist, then from the economic point of view, every visitor is very valuable for the show organizer.

From the aspect of kennel judges, canine events represent a certain type of business engagement. Kennel judges are real representatives of business tourists who are defined in literature as people traveling for business reasons (Davidson, Cope, 2003) while leaving from home for at least one night (Swarbrooke, Horner, 2001). According to the rules of the World Canine Organization (FCI - The Fédération Cynologique Internationale) and the rules of national kennel organisations, the organizer of the dog event is obliged to cover all expenses of the trip and accommodation for dog judge, as well as to pay a certain judge fee. Therefore, the main motive for traveling as dog judge could be business engagement. Business is considered as the main motive of business trips (Davidson, Cope, 2003; UNWTO, 2008), therefore dog judge who travels for a particular event, and at least spent one night at the place where the event is held, can be considered as a true representative of a business tourist. After the event, the judges mostly visit the famous destinations, buy souvenirs, or behave like every tourist, which is stated as one of the characteristics of business tourists (Davidson, Cope, 2003, Štetić, 2006, Šimčević, Nicić, 2007, Dragićević, 2012).

Canine manifestations represent very specific events. At first glance, if one considers the basic and essential reason for their organization (competition in the dog beauty or dog work), they represent sports events and event of a competitive character. The most important number of visitors are dog owners and dog breeders, among which a large number is professionally engaged in cynology. They are engaged in dog breeding and reproduction which causes the production and sale of puppies. The market value of puppies grows with better grades and a higher number of parents' titles. This further motivates breeders to visit a large number of dog competitions. For them, competitions are a chance to compare the quality of their dogs with the quality of dogs from other kennels and breeders. These events are chance to present their dogs in order to achieve the best possible placement in the competition, which will be a good reference for selling their dogs or choosing a dog for further reproduction. Thus, within these events cynology is present, not only as a hobby activity, but more and more as a certain kind of "production activity". Therefore, canine events also represent economic events.

Dog competitions in work and beauty have a fair character, since within them breeders present their dogs (products), compare their dogs with dogs of other breeders, maintain and create new contacts with other kennels, exchange ideas and information with dog judges, while dog handlers present their services. Consumer exhibitions, which always follow large dog shows, allow dog breeders to collect information about products in the field of dog food and equipment, as well as to buy certain products directly from the manufacturer.

However, there are many accompanying entertainment and recreational activities that are offered to visitors during the dog competitions. Visitors have opportunity to watch presentations of various activities with dogs, called dog sports. The most common form of activity is agility representing a type of dog sport in which the handler instructs the dog to freely run and 
overcome certain obstacles such as different ramps, bowls, tunnels, grooves, circles and other similar obstacles that make the path difficult. During these presentations, visitors are often allowed to participate and experiment with their own dogs. Dog dancing is a sport that represents a combination of obedience training and dance, in which the dog and his handler, along with music, perform a certain "dance" choreography. This could be very interesting and pleasant for the visitors. Mondioring is a kind of defensive dog sport, in which dogs show the ability to protect themselves and their owners in different conditions, and through various disciplines like obedience, defense and jumps. There are, also, other dog sports like flyball (catching balls). There are special canine events that are organized just to compete in these sports disciplines. But at large dog shows of all breeds, they are presented for their own popularization and popularization of cynology in general.

Therefore, having in mind all the listed characteristics of dog competitions canine events can be characterized as specific, thematic, interactive and public events with sports-recreational, commercial, business and entertainment character, within which dogs are judged and classified in beauty or a certain type of work. Getz (2007) explains that interactive events represent personification of person-person interaction or person-environment interaction, in contrast to passive observational events. Especially this interaction and participation in the event gives uniqueness to each event, which is important element in the of event recognition. Canine events could be consider as "participant event", which Getz (2007) describes as events that are organized and maintained just to make people participate in them, and not just observe it. Participants are more than visitors, since without the participants the event could not be maintained. Bjeljac (2006) also separates events according to participants and audience. He separates them on participant events (where participants are at the same time the audience) and presentation events (where the participants are separate from the audience). This is essential characteristic of the canine events, because without a participant or competitors, dog competitions could not be maintaned. Therefore, organizers of canine events are obliged to attract as many competitors as possible and create conditions for strong competition. A large number of competitors provide great number of business organizations as exhibitors within consumer exhibitions that follow dog events. All this is a good basis for attracting other visitors who are not competitive. Good planed canine competition can bring, among other things, significant economic benefits both for the organizer and the local community.

\section{Conclusion}

The main characteristic of the canine events is that they are participant event that are described in scientific literaure as events that are organized and maintained to involve people in them, and in which participants are more than visitors (Bjeljac, 2006; Getz, 2007). This is an essential feature of the canine events. Thus, the specificity of the canine competitions is reflected precisely in the mutual interaction of all participants, which gives unpredictability and uniqueness to every event, and what Getz (2007) points out as an important element in the recognition of one event.

Canine event participants also represent the most important tourist group, having in mind that they have to cross a significant distance in order to participate in dog competitions. They are very often professionally engaged in the breeding, selection, reproduction and sale of dogs. Therefore, their participation in the canine events is necessary in order to strengthen their market position. This makes cynology a specific production activity. During these events, breeders 
present their dogs as specific "products" and at the same time examine the market and create new business contacts. That makes them business tourists. On the other hand, other participants and visitors interested in buying dogs, have the opportunity to get a clearer insight into the "offer" of breeds during the event.

The significant content of large canine competitions is often consumer exhibition where different products for dogs are exposed and sold. In this context, canine events, besides the basic sport-recreational character, also receive economic significance. The entertainment and festival character of these events is reflected in the fact that in addition to the competition, visitors can also watch presentations of various dog sports and other accompanying entertainment and recreational activities. The conducted theoretical and field research indicate that the canine events (competitions in the work and beauty of the dogs) are characterized as specific, thematic, interactive and public events with sports-recreational, commercial, business and entertainment character, within which dogs are classified in beauty or a certain type of work. As such they can significantly contribute to the improvement of the tourism product of a certain area, as well as the entire touristic product of Serbia.

\section{References}

Avgousti, K. 2012. The use of events in the developmnet of the tourism industry: The Case of Cyprus, Event Management 16, 203-221

Bjeljac, Ž. 2006. Teorijsko-metodološke osnove manifestacionog turizma, Geografski institut „Jovan Cvijić", Beograd.

Bowdin, G. A. J., Allen, J., O’Toole, W., Harris, R., McDonnell, I. 2011. Events management (3rd ed). Great Britain: Oxford, Elsevier Butterworth-Heinemann.

Dragićević, V. 2012. Konkurentnost Vojvodine kao destinacije poslovnog turizma, Departman za geografiju, turizam i hotelijerstvo, PMF, Novi Sad

Felsenstein, D., Fleischer, A. 2003. Local festivals and tourism promotion: the role of public assistance and visitor expenditure. Journal of Travel Research 41(4), 385-392.

Formica, S., Uysal, M. 1998. Market segmentation on an international cultural-historical event in Italy. Journal of Travel Research 36(4), 16-24.

Getz, D. 1993. Festivals and special events. In M. A. Khan, M. D. Olsen, \& T. Var (Eds.), Encyclopedia of hospitality and tourism (pp. 789-810). New York, NY: Van Nostrand Reinhold.

Getz, D. 2008. Event tourism: Definition, evolution, and research. Tourism Management 29/3, $403-428$

Gursoy, D., Kimb, K., Uysalc, M. 2004. Perceived impacts of festivals and special events by organizers: an extension and validation. Tourism Management 25, 171-181

Hadžić, O. 2006. Stejkholderski pristup upravljanju održivim razvojem kulturnog turizma, doktorska disertacija, Departman za geografiju, turizam i hotelijerstvo, PMF, Novi Sad.

Higham, J., Hinch, T. 2002. Tourism, sport and seasons: The challenges andpotentials of overcoming seasonality in the sport andtourism sectors. Tourism Management 23(2),175-185.

Jackson, L. 2008. Residents' perceptions of the impacts of special event tourism. Journal of Place Management and Development 1/3, 240-255.

Light, D. 1996. Characteristics of the audience for "events" at a heritage site. Tourism Management, 17(3), 183-190. 
Matejevic, M., Wallrabenstein, K., Ristic, Z., Urosevic M., Drobnjak, D. 2013. Karakteristike kinoloskih manifestacija u Srbiji. Zbornik radova Departmana za geografiju, turizam $i$ hotelijestvo 42, 227-235.

Matejevic, M., Wallrabenstein, K., Ristic, Z. 2014. Dog show participants as tourist: attendance motivation factors. European Journal of Tourism Research 7/1,1314 - 0817.

Matejevic, M., Wallrabenstein, K., Ristic, Z. 2015. Tourist Dimension of Canine Events. Event Management 19/2, 291-302.

Mehndiratta, V. 2008. Event Management. Chandigarh, IND: Abhishek Publications, http:// site.ebrary.com/lib/belgrade/Doc?id=10416533\&ppg $=42$

O'Sullivan, D., Pickernell, D., Senyard, J. M. 2009. Public sector evaluation of festivals and special events. Journal of Policy research in Tourism, Leisure and Events 1(1), 19-36.

Štetić, C. 2006. M.I.C.E.. industrija - budućnost razvoja turističke destinacije. Turizam 10, 21-24. 